Huntington's disease great care will be needed to ensure that the test is accompanied by full information on the genetic implications.

An even more difficult question is whether testing should be undertaken diagnostically in a person known to be at risk who has minor or apparently unrelated symptoms. The mutation for Huntington's disease might not be the cause of the clinical problem, and such testing could in effect be prediction rather than diagnosis.

The unstable nature of the Huntington's disease trinucleotide repeat mutation, closely comparable to that responsible for myotonic dystrophy, ${ }^{14}$ makes likely some correlation between the degree of enlargement of the sequence and the age at onset of the disorder. Indeed, this has now been confirmed, ${ }^{2}$ but the range of variation for any given result seems likely to be too great to be clinically useful for individual patients.

A final problem is the possibility of stigmatisation in employment, insurance, and personal relationships. This is not new. It has already been encountered by those undergoing presymptomatic testing by linked markers and to some degree by most people with a family history of Huntington's disease. Mutation testing will, however, increase the potential for such problems and is yet another incentive for society to monitor and regulate the use of genetic testing generally if it is not to become abused.

The identification of the gene for Huntington's disease and the use of mutation testing in clinical practice will provide major challenges and problems for both families and professionals. It would be wrong, however, to overemphasise the negative aspects. For many people, testing will lift the shadow under which they have lived for many years, while the prospect of understanding the pathogenesis of the disease brings the possibility of treatment a step nearer. When a treatment is developed many of the present dilemmas of presymptomatic testing will disappear and true prevention of Huntington's disease may at last become a reality.

\section{PETER S HARPER}

Professor

Institute of Medical Genetics,

University of Wales College of Medicine,

Cardiff CF4 4XN

1 Huntington's Disease Collaborative Research Group. A novel gene containing a trinucleotide repeat that is expanded and unstable on Huntington's disease chromosomes. Cell 1993;72. repeat that

2 Snell RG, MacMillan JC, Cheadle JP, Fenton I, Lazarou L, Davies P, et al. Expansion of a specific trinucleotide repeat sequence in Huntington's disease. The molecular basis of phenotypic variation. Nature Genetics (in press).

3 Meissen GJ, Myers RH, Mastromauro CA, Koroshetz WJ, Klinger KW, Farrer LA, et al. Predictive testing for Huntington's disease with use of a linked DNA marker. $N$ Engl $f$ Med 1988;318:535-42.

4 Hayden MR, Robbins C, Allard D, Haines J, Fox S, Wasmuth J, et al. Improved predictive testing for Huntington's disease by using three linked DNA markers. Am $\mathcal{G}$ Hum Genet 1988;43:689-94.

5 World Federation of Neurology Research Group on Huntington's Disease. Presymptomatic testing for Huntington's disease. A world-wide survey. $\mathcal{f}$ Med Genet (in press).

6 Craufurd D, Dodge A, Kerzin-Storrar L, Harris R. Uptake of presymptomatic predictive testing for Huntington's disease. Lancet 1989;ii:603-5.

7 Brock DH, Mennie M, Curtis A, Millan FA, Barron L, Raeburn JA, et al. Predictive testing for Huntington's disease with linked DNA markers. Lancet 1989;i:463-6.

8 Tyler A, Morris M, Lazarou L, Meredith L, Myring J, Harper PS. Presymptomatic testing for Huntington's disease in Wales 1987-1990. Br $\mathcal{F}$ Psychiatry 1992;161:481-8.

9 Warner JP, Barron LH, Brock DJH. A new polymerase chain reaction (PCR) assay for the trinucleotide repeat that is unstable and expanded on Huntington's disease chromosomes. Molecular and Cellular Probes 1993;7:235-9.

10 World Federation of Neurology Research Group on Huntington's Disease. Ethical issues policy statement on Huntington's disease molecular genetics predictive test. $f$ Med Genet 1990;27:34-8.

11 Craufurd D, Tyler A, on behalf of the UK Huntington's Prediction Consortium. Predictive testing for Huntington's disease: protocol of the UK Huntington's prediction consortium. $\mathfrak{f}$ Med Genet 1992;29:915-8.

12 Tyler A, Ball D, Craufurd D. Presymptomatic testing for Huntington's disease in the United Kingdom. $B M 7$ 1992;304:1593-6.

13 Collinge J, Palmer MS, Dryden AJ. Genetic predisposition to iatrogenic Creutzfeldt-Jakob disease. Lancet 1991;337:1441-2

14 Harley HG, Rundle SA, Reardon W, Myring J, Crow S, Brook JD, et al. Unstable DNA sequence in myotonic dystrophy. Lancet 1992;339:1125-8.

\title{
How should another Camelford be managed?
}

\author{
By better planning and more openness
}

Five years ago 20000 people in the Camelford area of Cornwall were exposed to high concentrations of aluminium in their drinking water after 20 tonnes of aluminium sulphate was mistakenly put into the water at Lowermoor Water Treatment Works. They were exposed for a few days, as the fault was detected and corrective measures were started within six hours. The water tasted unpleasant because of its acidity and aluminium content; it also contained abnormal amounts of copper and zinc dissolved from pipes. The initial toxicological assessment was that the limited exposure would not cause acute or chronic disease.

Two years later, however, 400 people had illnesses that they attributed to the incident. There is objective evidence from a few patients that skeletal and neuropsychological effects were present for 12 to 18 months. ${ }^{1}$ An expert review, chaired by Professor Dame Barbara Clayton, could not find biochemical explanations for the reported illnesses but interpreted the symptoms as "real mental and physical suffering" resulting from the anxieties created by the incident. ${ }^{23}$ The anxiety and the disputes about the effects on health would have been less if the public had been better informed about the incident from the outset. Those who may have to manage similar incidents should prepare their plans for high quality epidemiological assessment and public relations.

The plans should accommodate a variety of unpredictable incidents. Contamination may be by chemicals, radiation, or micro-organisms, and water is only one of the ways by which pollution reaches human populations. A difference exists between acute incidents and persistent contamination, although this distinction is often confused by the public, who suspect that the acute incident is the tip of an iceberg.

Acute chemical pollution of drinking water can arise from mistakes made in treatment or from industrial or agricultural chemicals reaching water sources after accidents, fires, or incorrect disposal of waste. Normally the contamination is detected and controlled by the National Rivers Authority and the water companies, and the public is not at risk. Small problems are surprisingly common: 23000 incidents occurred in England and Wales in 1988, on a rising trend. ${ }^{4}$ Incidents on the scale of Camelford are rare. They require special handling because of the needs for alternative water supplies to many homes, public information, and a thorough assessment of the risks to health. These measures cannot be left for the water industry to manage itself.

The participation of multiple agencies, both local and national, requires careful organisation. We cannot assume that the organisation is in place for chemical incidents. ${ }^{5}$ Collaboration has been hindered by the repeated reorganisation of the public health services, the water industry, and central government departments. It is essential that all the agencies are informed immediately when pollution is detected, but there will be doubt in the early stages that the 
pollution has occurred and might be a risk to health. As in most processes operating to exacting standards, most alarms will be false or for minor deviations from normality.

The preliminary assessment of the risks to human health is difficult. Exactly what chemicals are involved may not be known, especially if the incident has started with a fire or explosion. Even when the incident starts with a single chemical in known amounts there may be unmeasured secondary chemical reactions, such as the acidic dissolution of the water pipes in the Camelford incident.

In such incidents, until the results of analysis are available the concentrations of the polluting chemicals in the water from the consumers' taps will also be uncertain because the flow of water in the distribution system is never constant and, often, water from several sources is mixed. The next uncertainty is the amount of water, and so the dose of pollutants, consumed by the exposed people. There is likely to be uncertainty about the toxicity of the pollutants in the dilutions estimated to be present in the contaminated water. Data from rats fed on a diet of the chemical, or from industrial exposure of men, may be irrelevant to the short term exposure of children and pregnant women.

Expert advice can be obtained from the National Poisons Information Centres, the Department of Health, and other national centres. Whatever the advice, a population study of the effects on health is likely to be necessary when the incident is a rare or unique exposure. It is ethical to turn an unusual event into an opportunity to learn about the effects of pollution, and people will be reassured more than frightened by the news that the preliminary health assessment is to be backed up by an epidemiological investigation with toxicological support.

The number of people who can conduct epidemiological investigations of acute problems in local populations is growing. Many of the consultants in communicable disease control in district health authorities have an interest in non-microbial environmental hazards. Their joint plans with their local environmental health departments can cover incidents of chemical as well as microbial pollution. Some of the regional epidemiologists appointed to support these consultants have had an active role in incidents of chemical pollution. University departments of public health are not only expert in epidemiology but are also likely to be regarded as independent. Occupational health physicians and the Employment Medical Advisory Service combine epidemiological and toxicological knowledge but may be perceived as on the side of industry.

More attention should be given to public relations in major incidents. The expert review criticised the media for maintaining the fears of the people in Camelford. ${ }^{23}$ There was, however, a credibility gap between the early official advice to the public and what people were experiencing themselves. Public trust lost in this way is rarely regained. The staff of the public utilities and local government and health care staff may think that they have enough experience of crises in their usual work to manage the public relations by themselves in a major incident. But they are wrong: senior managers will have more than enough to do in their daily business plus their professional work arising from the incident. The services of public relations firms specialising in crisis management should be considered when emergency plans are being made.

There must be more certainty about who is available to do the fieldwork in a major incident. Environmental health officers have heavy workloads attending to the non-medical aspects of environmental hazards. Public health doctors have few directly managed staff and depend on good will and negotiation to get help in emergencies. Good will is often abundant in major incidents because most people see the common cause and wish to take part, but good will is not enough. The contracts of general practices and health service trusts should require their participation in major incidents, and health authorities should be prepared to fund the medical and nursing work entailed.

R T MAYON-WHITE

Oxfordshire Health Authority, Consultant public health physician

Oxford OX3 9DZ

1 McMillan TM, Freemont AJ, Herxheimer A, Denton J, Taylor AP, Pazianas M. Camelford water poisoning accident: serial neuropsychological assessments and further observations on bone aluminium. Hum Exp Toxicol 1993;12:37-42.

2 Lowermoor Incident Health Advisory Group. Water pollution at Lowermoor, north Cornwall. Truro: Cornwall and Isles of Scilly Health Authority, 1989.

3 Lowermoor Incident Health Advisory Group. Water pollution at Lowermoor, north Cornwall. Second repor. London: HMSO, 1990.

4 Wilson HC. The hazard of water pollution and the risk to public health. Health and Hygiene 1990;11:60-4.

5 Baxter PJ. Major chemical disasters. BMf 1991;302:61-2.

\title{
Seclusion in prison strip cells
}

\author{
A practice to be ashamed of
}

Official prison policy is that prisoners at risk of suicide should not be placed in "strip cells" for long; if such cells have to be used because no protective room is available then they should be used only for short periods. Yet the evidence is that strip cells may still be routinely used to house suicidal prisonerssometimes for many days. In their 1991 annual report, for example, the Board of Visitors of Bristol Prison alleges that a prisoner was placed in a strip cell continuously for 28 days after attempting suicide. Why are suicidal prisoners kept in these cells and what are the alternatives?

If a protective room is specifically designed to provide a safe environment what then is a strip cell? A stripped room, to give it its official title, has been described as a cell of bare stone, often without decoration, with little or no natural light and containing only a mattress, a terylene blanket, and perhaps a cardboard chair. The occupant must don terylene clothing, is allowed no possessions, and is deprived of intellectual and social stimulation. A prison officer observes the occupant through a spyhole every 15 minutes.

How often are stripped rooms being used to contain suicidal prisoners? Unlike disciplinary seclusion, for which careful records are mandatory, there has been no national system registering the purpose, frequency, or duration of seclusion on medical grounds. We know that there were 746 recorded episodes of self harm with suicidal intent in 1991-2, and Gunn et al found it common practice to transfer prisoners at risk of self harm to a strip cell after a brief psychiatric assessment. ${ }^{1}$ Limited data do exist comparing the frequency of use of protective rooms and strip cells in every health care centre (formerly known as prison hospital wings) over five non-consecutive weeks in 1992. Across the 130 prisons of England and Wales protective rooms were 